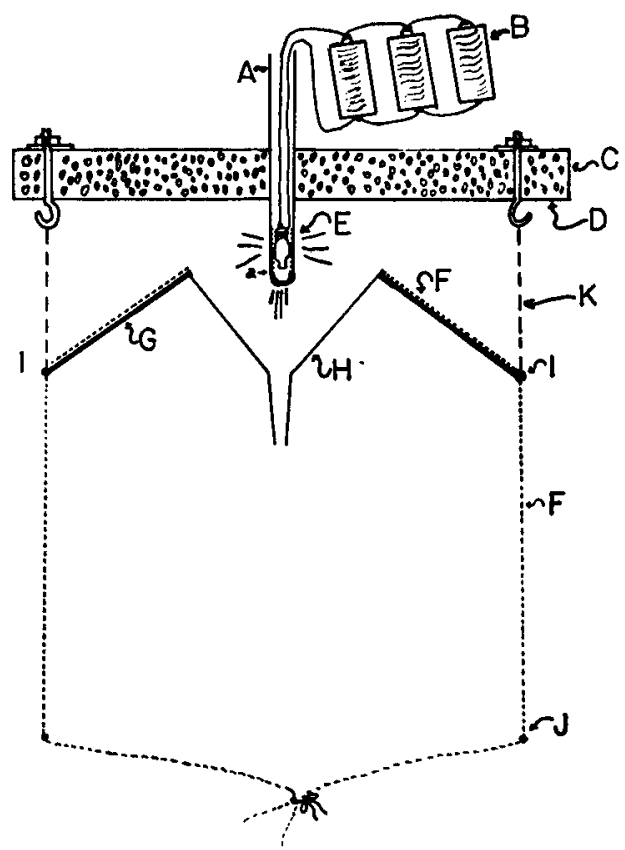

FIG. 1. A physiological light trap for Cladocera and other animals. A, large test tube piercing float; $\mathrm{B}$, three 1.5 volt flashlight batteries in parallel taped around test tube; C, float with four suspension hooks; $D$, reflecting surface; E, 2.2 volt pen-light bulb; F, bolting cloth; $G$, six $1 / 8$-inch rod supports; $H$, ordinary aluminum funnel; $I$, $J$, quarter-inch metal rings; $K$, cylinder of $1 / 4$-inch mesh screen as a fish guard hung on hooks.

Sida crystallina (Müller), Daphnia longispina hyalina (Leydig), Simocephalus vetulus (Müller), Ceriodaphnia reticulata (Jurine), Bos- mina obtusirostris (Sars), Chydorus globosus (Baird), Kurzia latissima (Kurz), and Lepto. dora kindtii (Focke).

Other organisms caught include the phantom larvae of the genus Chaoborus, the swimming larvae of the caddis fly genus Triaenodes, and various water mites.

Single catches often numbered hundreds of thousands of specimens.

The collection of carnivorous forms (Leptodora, Chaoborus, and water mites) has its disadvantages. On one occasion, when the contents were removed from the trap at midnight, several hundred Sida and Simocephalus were seen. By morning all save two were gone, eaten by the two hundred water mites that were also taken.

The basic principle of this trap, that of using one kind of light to attract and so condition an organism that a second kind of light will produce a fateful response, should be of widespread application. A trap which samples efficiently a group of organisms with common behavior pattern should be especially useful in ecological studies. Endless combinations of light responses can be used to create a large variety of traps, and by varying their complexity the traps could be made as specific as desired.

\section{REFERENCES}

Baylor, E. R., and F. E. Smith. In press. The orientation of Cladocera to polarized light. American Naturalist.

Smith, F. E., and E. R. Baylor. In press. Color responses in the Cladocera and their ecological significance. Amer. Nat.

EDWARD R. BAYLOR Frederick E. SMITH

Department of Zoology, UNIVERSITY OF MICHIGAN, Ann Arbor, Michigan

\title{
AN INSTRUMENT FOR QUANTITATIVE STUDIES OF PHOTOTAXIS
}

The phototactic and geotactic responses of Cladocera have recently been investigated by Baylor and Smith and by Smith and Baylor (both papers accepted for publication in American Naturalist). The data reported were qualitative. Quantitative information on the phototactic behavior of Cladocera can be secured with the photoelectric apparatus described below.

While Daphnia magna (Straus) was the experimental animal used throughout the present studies, the apparatus should work equally well for other swimming organisms which show positive phototaxis.

The apparatus consists of an aquarium containing Cladocera plus the appropriate photo- electric devices for alternately turning off one light source and turning on another.

The experiments were carried out in a small glass aquarium $8 \times 10 \times 12$ inches. The inside of the aquarium was lined with dull surface black plastic to reduce internal reflections. Two Erb and Gray microscope lamps were arranged to give vertical beams of light through the water to the photoelectric cells beneath the aquarium (Fig. 1). Two one-inch round holes with centers eight inches apart were cut in the black plastic lining of the top and bottom to allow the light to pass through.

Vickers Ltd. barrier-layer cells were used for measuring the population density of animals 


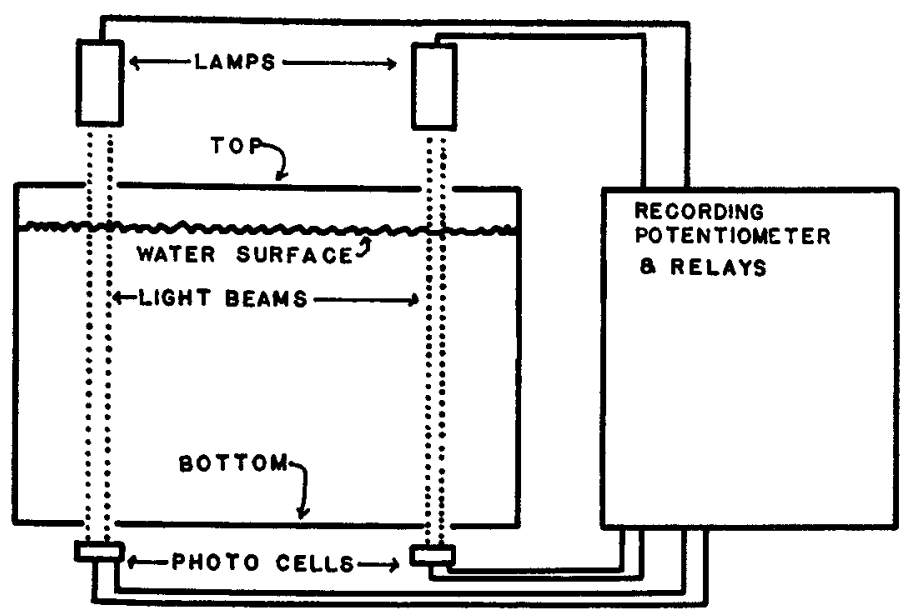

FIG. 1. Apparatus for quantitative studies of phototaxis.

in the light beam (i.e., decrease in light transmission). The signal from each barrier-layer cell was fed to a recording potentiometer such as a Brown Strip Chart Recorder. This instrument is capable of tripping a control relay whenever the intensity of light on the appropriate photocell falls to any predetermined level. The control relay is a ratchet relay which turns on one light and turns off the other simultaneously whenever the relay is pulsed. Since the animals are positively phototactic the result is a shuttling back and forth from one light to the other, the animals changing the lights by their own actions. In addition to controlling the lights the instrument records continuously, drawing each curve of falling light intensity versus time on a moving roll of paper.

No attempt was made to convert the recording potentiometer and barrier-layer cells to a ratio circuit to avoid the uncertainties of line voltage variation. Instead the lights were operated from a Sorensen constant voltage regulator which held the voltage to plus or minus 0.1 per cent.

The phototactic responses to different wavelengths of light were investigated using Corning
Glass filters to isolate the desired bands of light. The intensity was controlled with neutral density filters of screen wire of various sizes.

The apparatus yields the following information: (1) average velocity of the population; (2) the time of arrival in the light beam of any given percentage of the population; (3) distance travelled necessary to kill one-half the population at any given velocity; (4) the effects of wave length and intensity of the light on the above.

Preliminary data for $D$. magna indicate that both intensity and wave length have an appreciable effect on the velocity of locomotion. At a velocity of one foot per minute, 50 per cent of one experimental population was killed in six hours. The surviving members of the population were considerably more transparent at the end of the experiment than at the beginning, due apparently to evacuation of the gut and to use of stored food substances.

EDWARD R. Baylor

Department of ZoOlogy, Frederick E. Smith

UNIVERSITY OF MiChIGAN, Ann Arbor, Michigan

\section{RESURGENT POPULATIONS OF LITTORAL MARINE INVERTEBRATES AND THEIR DEPENDENCE ON OCEAN CURRENTS AND TIDAL CURRENTS ${ }^{1}$}

A curious departure from the usual local fluctuations in the populations of marine invertebrates is the sudden appearance of a resurgent population in which the numbers may

\footnotetext{
1 Contributions from the Scripps Institution of Oceanography, of the University of California. New series, No. 604 .
}

be hundreds or thousands of times larger than in the immediately preceding or following years. On sandy beaches in several parts of the world are species of bivalve mollusks belonging to the genus Donax. Some of these species occasionally experience an enormous increase in the numbers of individuals constituting a local population for one to three years and then re- 